\title{
Taking Stock of Myanmar's Ethnic Peace Process and the Third Twenty-First Century Panglong Conference
}

\author{
N. Ganesan
}

The Third Panglong Peace Conference convened in Naypyitaw in July 2018 has led to the accession of two more armed groups to the Nationwide Ceasefire Agreement bringing the total number of signatories to ten groups now. Conversely, this development has weakened the United Nationalities Federal Council that previously housed the non-signatories collectively. There were far less agreements this time around and major sticking points include the military's insistence that the armed groups agree not to secede from the Union of Myanmar which the latter have refused thus far. The military is also interested in discussing disarmament, demobilization, and reintegration while the armed groups are keen on broader security reforms. China again facilitated the Northern Alliance's attendance of the meeting.

Keywords Myanmar peace process, ethnic armed groups, Northern Alliance, Nationwide Ceasefire Agreement, Myanmar-China relations

\section{Introduction}

The Myanmar government convened the Third Twenty-First Century Panglong Conference in the country's administrative capital city Naypyitaw in July 2018. This is the third meeting of a new series of peace dialogues initiated by the National League for Democracy (NLD) government that came into power in April 2016 and was meant to build on the Nationwide Ceasefire Agreement (NCA) that was signed between eight ethnic armed groups and the Thein Sein government in October 2015. Consequently, it is part of an ongoing process that is meant to eventually lead to the cessation of violence between the armed groups and the military.

There were a number of notable developments in the lead up to the Conference. The first of these was the accession of two more armed groups to the NCA. Both the New Mon State Party (NMSP) and the Lahu Democratic 
Union (LDU) signed onto the process, bringing the number of signatories up to ten groups now. The Karenni National Progressive Party (KNPP) was originally expected to sign on as well but had a change of heart. Other major developments include the negative sentiments echoed by many of the signatories to the process, the Chinese facilitation for the presence of the leaders of the Northern Alliance at the Conference, and the continuation of armed conflict between members of the Northern Alliance and the military. Additionally, there have also been several instances of fighting between NCA signatories and members of the Northern Alliance.

This article seeks to trace the current state of the ethnic peace process and identify the major developments that have occurred in the lead up to the July Twenty-First Century Panglong Conference. Organizationally it is divided into five major sections. The first section traces the major developments that have occurred between the Second and Third Panglong Conferences. The second section then identifies the major issues during and after the Third Conference and the following third section identifies the gains and setbacks to the process that have occurred thus far. The fourth section places the entire peace process within the broader national context and how it has impacted the relationship between the ethnic armed groups and the government and the military and how those developments have in turn impacted the country's overall political process and democratic transition. Finally, the fifth section examines the impact of China's mediation in the peace process.

\section{Major Developments Leading Up to the Third Panglong Conference}

The most significant development in the lead up to the Third Panglong Conference was the accession of two more ethnic armed groups to the NCA in February 2018. While there were earlier expectations and even premature announcements that the NMSP and the KNPP would sign onto the NCA, that optimism fell through (Lun Min Mang 2017). The KNPP was extremely critical of an incident in which it accused the military of executing four of its members in cold blood. Notwithstanding a number of meetings over the issue it was never really resolved. The NMSP is a smaller armed group while the LDU is even smaller, so while the new signatories increased the number of signatories committed to the NCA, the situation was not a major breakthrough. However, it should be noted that the Mon are well represented in many parts of the country including Yangon and boast an older and more refined civilization than the majority Bamar ethnic group.

These new accessions again weakened the United Nationalities Federal Council (UNFC) that had previously served the corporate interests of the nonsignatories to the NCA. The three remaining members are the Karenni National 
Progressive Party, Shan State Progress Party/Shan State Army, and the Arakan National Council/Arakan Army. And since the Shan State Progress Party and the Arakan Army also claim membership in the Northern Alliance that is led by the United Wa State Army (UWSA), the KNPP was to all intents and purposes the only remaining member of the UNFC and that hardly made it a collective corporate entity. Shortly afterwards, however, the UNFC announced that it had accepted back two other armed groups that were previously part of the grouping. The two groups are the Chin National Front (CNF) and the Kachin National Organization (KNO) (Chan Thar 2018). Nonetheless, the departure of the NMSP and the LDU have continued the weakening of the UNFC as the premier representative of the non-signatories, and given the recent trajectory of developments it is likely to become even less relevant over time. Consequently, the two major corporate groups are now the NCA signatories and the Northern Alliance.

The Northern Alliance was formed in late 2016 with seven ethnic armed groups that are non-signatories to the NCA. And among these seven, four of them-the Kachin Independence Organization/Army (KNO/A), Arakan Army (AA), Myanmar National Democratic Alliance Army (MNDAA-Kokang), and Ta'ang National Liberation Army (TNLA) - are in a state of active combat with the Myanmar military. In fact, since the current NLD-led government took office in April 2016, fighting between these groups and the military has not abated. Rather it has intensified significantly in the northern Shan states and in Kachin state. Recent attempts by the military to gain ground in the gold, amber, and jade mining areas in Kachin state in particular has led to a large number of internally displaced persons. Since April 2017, the Northern Alliance has been led by the UWSA and it has indicated that it is not in favor of the NCA as currently constituted. Additionally, the group insists on collective negotiations with the government and has sought the assistance of China to be an honest broker between it and the government. The Union Political Dialogue Negotiating Committee (UPDNC) is the official interlocutor representing the Northern Alliance.

While this dynamic was ongoing among the non-signatories, the Karen National Union/Karen National Liberation Army (KNU/KNLA), which is the largest ethnic armed group among the signatories, voiced concern over the seemingly stalemated situation in the peace process. In fact, the KNLA was involved in armed conflict with the military in Phapun district in Karen state in March 2018 (Nyein Nyein 2018a). While the military claimed that it was building a road in the area, the KNLA stated that it was not informed of the intrusion into its territory as required under the terms of the NCA (Karen News 2018). Additionally, the KNLA fears that road construction will simply facilitate the military's transport and deployment of heavy weapons in the area. This conflict and subsequent clashes led in turn to the displacement of some 1,500 Karen 
civilians from the neighboring areas.

The Chairman of the KNU, General Saw Mutu Say Poe, was even more blunt in his criticisms of the peace process and the Panglong Conferences. During a meeting of the Peace Process Steering Committee (PPSC) of the ethnic armed groups that brings together NCA signatories held in Chiangmai, Thailand in early July, he pointed out the need to recognize the existing diversity in the country and the importance of amending the 2008 Constitution in order for the peace process to progress. He then went on to add that para 22 (d) of the NCA explicitly recognizes the need to amend, supplement, and cancel laws arising from the Union Peace Conference (Maung Htoo 2018a). Earlier in May, the KNU Concerned Group, which is comprised of some current and retired KNU leaders, noted that dependence on the military for all security matters works against the cessation of conflict. The group went on to claim that the NLD government does not have the power to work with the ethnic armed groups to secure peace (Lawi Weng 2018b). Finally, it noted that the military's ongoing actions threaten to derail the NCA, which will in turn destabilize the peace process and lead to a new round of conflict.

The Karen Peace Support Network, an organization that is comprised of more than twenty Karen civil society groups, similarly accused the military of blocking attempts to build a federal political system in the future (Naw Betty Han 2018a). It also noted that the government and the military have thus far utilized the peace process simply to centralize power and consolidate their land and natural resource holdings. While there was a short respite to the fighting following a meeting between KNU chairman General Saw Mutu Say Poe and Senior General Min Aung Hlaing in late May, the fighting restarted in August and a total of fiftyseven skirmishes were reported between March and October (Naw Betty Han 2018b). All in all, it may be noted that the Karen community is clearly dissatisfied and unhappy with the way the peace process is evolving and is seeking to publicly place its grievances on record.

\section{Major Issues in the Third Panglong Conference}

When it was held in July 2018, the Third Panglong Conference had already been postponed four times. This postponement is in line with previous meetings when the ethnic armed groups regularly seek more time to discuss issues with their constituents and also hold meetings between themselves in order to try and coordinate their positions. Notwithstanding such attempted coordination, the groups have always complained that the military simply stonewalls them on issues that it is unprepared to discuss. They also note that the military constantly references the 2008 Constitution during negotiations. The military has also required the armed groups to renounce the threat of secession from 
the Union when negotiating federalism. This offer was one of the important safeguards offered to the ethnic groups by General Aung San when he negotiated the Panglong Agreement in 1947. Consequently, the NLD government's choice of name for the peace dialogue contains both promise and peril for the state (Ganesan 2017, 329).

Other issues that the armed groups have raised in the previous meeting include gender equality and 30 percent representation for women in the peace process. Especially important is the equitable sharing of land and natural resources between the government and the armed groups. For security issues, the armed groups are interested in broad based security sector reform that includes the formation of a federal army while the military appears only interested in disarmament, demobilization, and reintegration (DDR) of the ethnic armies. None of the ethnic groups, including the early NCA signatories, have endorsed disarming thus far and this is likely to be one of the most protracted and sensitive issues. It is likely that the armed groups will press for international monitoring of any such developments. Leading members of the armed groups have also noted that the military and the government appear to be on the same side during the negotiations and the former has indicated that it does not mind if the peace process fails (Nyein Nyein 2018c).

General Min Aung Hlaing's speech at the Conference was considered controversial by the armed groups since he attributed the continued conflict to the groups rather than the government or the military. Additionally, his remark that the Myanmar military represents the state and the people drew swift condemnations from the armed groups and social media users. NLD party members and lawmakers were also unhappy with this sweeping assertion (Ye Mon 2018). These groups do not wish to be associated with the military that has been responsible for so much political violence in the country and do not regard the military as representative of their groups or aspirations.

The Northern Alliance was issued an invitation to attend the meeting and was present. Following a coordination meeting in Panghsang, the capital of Wa state, in early July, members of the seven armed groups in the Alliance attended the Conference through arrangements made by China from Yunnan province. This group has sought to negotiate with the government and military as a corporate body and has refused to sign the NCA as it stands having earlier asked for some revisions (Lawi Weng 2018c). The real surprise in the meeting was the Wa declaration that it would sign the NCA if it was allowed to withdraw from it later. Such a possibility was certainly not envisaged by the government or the military and the declaration, to all intents and purposes, fell on deaf ears. Interestingly, General Min Aung Hlaing met with only leaders of the four armed groups in the Northern Alliance that had preexisting bilateral ceasefire arrangements with the military. It may be recalled that this was the first stage prior to the peace process before it was consolidated at the state level followed 
by the signing of the NCA at the national level. The four groups are the UWSA, Kachin Independence Army (KIA), National Democratic Alliance Army (NDAAMongla Group), and the Shan State Army-North (SSA-N).

The remaining three groups that are currently in active combat with the military, TNLA, AA, and MNDAA-Kokang, were hosted by Deputy Commanderin-Chief General Soe Win instead (Ye Mon 2018). It might be noted that the KIA is also in a state of active combat with the military after its earlier bilateral ceasefire agreement collapsed in June 2011. While the UPDNC that represents the Northern Alliance had points for discussion, these were not entertained since, as non-signatories to the NCA, these groups only hold observer rather than participant status.

When the meeting was concluded it was announced that there are plans to hold another meeting this year and two more in 2019. Given the history of postponements, a similar situation is likely to evolve. During her closing address, Aung San Suu Kyi also noted the importance of engaging in security sector reform as part of the peace process (ibid.). This is likely to be wishful thinking given the serious differences between the position of the military and the ethnic armed groups on such reform.

\section{Gains and Setbacks to the Peace Process}

The ethnic peace process is an ongoing and fluid one that seeks to build on the 2015 NCA. And as a process it has had its share of achievements and setbacks. Among its achievements, the most obvious is the fact that as a process it has continued. And notwithstanding misgivings on all sides, the fact that the process has continued without interruption is in itself an achievement. In other words, the simple fact that all the parties involved think it worthy to move the process forward is in itself an achievement. The second and perhaps most important structural achievement is the inclusion of the two new armed armed groupsthe NMSP and the LDU-into the NCA. This addition has increased the number of groups that have acceded to the NCA and should be regarded as a sign of progress. However, it should also be noted that the NMSP has registered negative sentiments after signing on to the NCA. Leaders of the group have indicated their frustration with the peace process despite having signed onto the NCA in February 2018 (Nyein Nyein 2018d).

The third major and visible achievement is the presence of members of the Northern Alliance at the meeting. Although the seven groups that are part of the Alliance have always articulated their preference for holding only collective meetings with the government and the military, their collective presence is an indication of the group's continued engagement as part of a broader confidence building measure. Since the grouping brings together two of the largest of the 
ethnic armed groups in the UWSA and the KIO/KIA, the group's inclusion is important for any nationwide resolution of the conflict with the ethnic groups. The nuanced dynamics of the group's meetings with the military in particular indicates the continued tense situation with three of the armed groups within the broad coalition that are currently in active combat. This point was driven home by the fact that Senior General Min Aung Hlaing met with the four groups with which that the military has a better past relationship-UWSA, NDAA, Shan State Progressive Party/Army (SSPP/SSA), and the KIO/KIA. Among these four groups, the military is also involved in heavy fighting with the KIA after the collapse of the bilateral ceasefire agreement in June 2011. Nonetheless, the existence of a previous agreement privileges the group in the eyes of the military.

It was the Deputy Commander Vice General Soe Win who met with the remaining three groups-the AA, MNDAA, and TNLA (Eleven Newsmedia 2018a). In the past, the military has insisted on their complete surrender before their acceptance into the peace process. This distinction was made since these three groups are regarded as being of a relatively recent vintage, do not have an existing bilateral ceasefire agreement, and have staged brazen attacks on border towns and the military in the past. All three groups had also collaborated and fought alongside the KIA in the past prior to the formation of the Northern Alliance and its subsequent leadership by the UWSA.

Among the setbacks to the peace process is that fighting has continued unabated. On the one hand there is regular fighting between the military and the KIA, TNLA, and AA. In fact, engagements with the KIA have become much more intense and widespread as the government tries to wrest control of areas around the town of Lanai in Kachin state that are known for gold and amber deposits. Fighting with the TNLA and AA has also ratcheted up especially in the northern Shan states leading in turn to widespread displacement of civilian populations in both Kachin and Shan states and, thus, increasing the number of internally displaced persons (IDPs). A second set of conflicts involves the Restoration Council of Shan States (RCSS) which is a signatory to the NCA and the TNLA and the SSPP/SSA. These skirmishes are mostly about territorial control and troop movements and have not let up. Similar skirmishes have sporadically occurred between the NMSP and the KNU since 2016, especially around Yephyu in the Tanintharyi Division (Lun Min Mang 2018). Consequently, fighting is not simply restricted to that between the military and the ethnic armed groups, but also includes inter-ethnic group violence.

Another setback has been the fewer number of items on the agenda in the most recent Panglong Conference and accusations that the military effectively has a veto on the agenda in terms of it not agreeing to discuss issues that are regarded as non-negotiable or out of bounds. Political issues typically fall into the first category and the ethnic groups charge that without inclusion of such items there cannot be progress in the dialogue process (Irrawaddy News 2018). For the 
military, the ethnic armed groups should also renounce the right of secession, something that they are unprepared to do. On the issue of disarming, none of the armed groups have publicly indicated that they are willing to disarm, not even the early signatories of the NCA. In this regard, the armed groups regard the retention of weapons as the only sure way to ensure that their interests are not ignored and also an insurance should the peace process eventually fail. In fact, most of the ethnic groups have thus far utilized a twin policy of competing in the polls through legitimately registered political parties on the one hand while retaining fighting capacity on the other. This way they are able to take advantage of the democratic process and ensure parliamentary representation even as some of them violently engage the military. Most recently some parties have announced their intention to merge in order to seek stronger representation than that won in the 2015 election when there were a total of fifty-nine ethnic parties that accounted for a total of 64 percent of all registered political parties (Nan Lwin 2018a). That fragmentation had led in turn to a four percent decline in the number of seats won when compared to the 2010 election. Consequently, leaders of these parties feel that consolidation rather than fragmentation will yield much more positive results in electoral contestation in the future and parliamentary gains in the forthcoming 2020 national election.

\section{The Relationship between the Ethnic Armed Groups, Government, and Military}

As mentioned in the previous section, whereas the relationship between the ethnic armed groups is well managed for the most part, some of the groups have been fighting among themselves over territory. Such occurrences appear most common in the Shan states and the Tanintharyi Division where the ethnic Mon and Kayin live in close proximity to each other. And while signatories to the NCA have generally been cordial towards each other and continue to hold meetings both before and after the Panglong Conference in order to present a united front, at the individual level they have often been unable to convene meetings for intraethnic consultations at the state level. Such attempts have been thwarted by the military on a regular basis.

Similarly, among the non-signatories grouped together in the Northern Alliance, the groups have generally co-existed peacefully. While four members of the group are in active combat with the military, this has not spilled over to the remaining three groups who regularly continue to meet under the leadership of the Wa or in China. Both the signatories and non-signatories also regularly meet in Chiangmai to coordinate their positions and iron out differences. In fact, shortly after the July 2018 Panglong Conference, the United Nationalities Alliance that brings together sixteen ethnic political parties issued a statement that peace 
should be achieved on the basis of equality, autonomy, and the establishment of a democratic federal union in the spirit of the original Panglong Agreement (Min Naing Soe 2018). Additionally, the leaders of the groups have issued a statement that they will not offer a guarantee not to secede from the Union as it is currently constituted (Lawi Weng 2018d). The leaders maintained that this was the original position of the ethnic leaders at the 1947 Panglong Conference and since there has been little progress in the peace process there is no reason to abandon it. This position is naturally unacceptable to the military that has always maintained that the unity of the state and all territories is sacrosanct. The ethnic armed groups have already announced that the groups will meet in two stages-first a meeting of the NCA signatories and the second involving all ethnic armed groups-in order to coordinate their positions and iron out differences ahead of the Fourth Panglong Conference (Eleven Newsmedia 2018c).

\section{The Impact of China's Mediation}

The Northern Alliance's participation in the peace process continues to be arranged by China and its Special Envoy Sun Guoxiang who regularly visits Naypyitaw and meets with leading members of the government as well as the military. In this regard, China has consolidated its position as the intermediary between both parties and the Northern Alliance, many of whose members are ethnic Chinese like the Wa and the Kokang who regard China more favorably than the Myanmar government and military. In fact, it was China that arranged a meeting between the leadership of the KIO/KIA and the military in Tarli, Yunnan province in early August after the Third Panglong Conference (Eleven Newsmedia 2018b). Unfortunately, nothing positive came out of that meeting.

China's bilateral relationship with Myanmar has strengthened significantly recently and there are number of both internal and external reasons for this development. Internally, China's ability to engage the Northern Alliance and regularly persuade its leaders to attend the Panglong Conference and negotiate with the Myanmar government and military has won it local recognition. The Northern Alliance has clearly indicated that it seeks support from China in the peace process (Nyein Nyein 2018b). While the military and government may not necessarily view the Northern Alliance's close relationship with China as being in the country's national interest, a more pragmatic approach to try and resolve the conflict has been adopted thus far. This pragmatic approach allows the Myanmar government and military to accept China as an honest broker in the peace process. And China has reciprocated this trust by attending to the mediation of the conflict seriously and with commitment and resources. The appointment of senior diplomat Sun Guoxiang who is devoted specifically to the process has also strengthened China's involvement in the peace process. An indication of his 
credibility is his regular meetings with top government officials in Naypyitaw and Senior General Min Aung Hlaing from the military. Most recently he arranged for a meeting between the three ethnic armed groups that the military had previously refused to deal with - the AA, MNDAA, and TNLA — and the government's Peace Commission (PC) in Kunming, Yunnan province (Maung Htoo 2018b).

Externally, China has sheltered Myanmar from international criticism in the United Nations and related international bodies against its treatment of the Muslim minority in Rakhine state which has been terrorized and displaced (Reuters 2018). In fact, the Myanmar government does not even use the term Rohingya for fear that it would then allow the group to claim the same status as one of the original 135 ethno-linguistic groups that were catalogued by the British colonial government. Such a claim would entitle it to rights enshrined in the country's Constitution as an indigenous group. And the harsh criticism of Myanmar's treatment of this group and the military offensives against the Shan and Kachin groups has led to targeted sanctions against the military commanders deemed responsible. The atrocities against the Rakhine Muslim population, who are derogatorily referred to as Bengali to suggest that they are illegal migrants from Bangladesh, has been documented and there are efforts underway to repatriate them back to Myanmar. China regards such developments as falling within Myanmar's domestic affairs although it has attempted to assist in the repatriation process and has arranged talks between the two countries. It is also interested in keeping Western countries and international organizations away from Rakhine state where it has significant interest and investments (Lawi Weng 2018a). The port and oil and gas terminals at the city of Kyaukphyu are central to China's Belt and Road Initiative (BRI) to link China's Yunnan province to the Indian Ocean. This linkage will allow the country to have strategic access to the Indian Ocean via a route other than the South China Sea where its presence is regularly contested. Additionally, the oil and gas pipelines allow China to bypass the Strait of Malacca for the transport of vital raw materials and save it time and money.

The prison sentence meted out to two reporters from Reuters for documenting the massacres in Rakhine state has also resulted in Myanmar's further international isolation. And the convergence of international criticisms and sanctions has once again had a displacement effect of drawing Myanmar closer to China. The last two years have witnessed large numbers of NLD lawmakers visit China with reciprocal visits from Chinese leaders and a strengthening of ties between the NLD and the Communist Party of China (CCP) as well (Htet Naing Zaw 2018; Nan Lwin 2018b). This was certainly the case from 1990 to 2010 when the country was exposed to wide ranging international sanctions before these were lifted in order to reward the Thein Sein government's democratic reforms in 2011.

China has capitalized on this new found appreciation and gone on to 
strengthen its bilateral relationship with Myanmar in a number of other areas as well. For instance, the two countries signed a Strategic Cooperation Framework Agreement in April 2018 and an agreement has been reached to set up a Myanmar-China Business Council to promote trade and investments between the two countries (Nilar 2018a). And in September 2018, the countries signed a Memorandum of Understanding (MoU) to build a China-Myanmar Economic Corridor (Nan Lwin 2018c). The Corridor, estimated at 1,700 km in length, is expected to connect Yunnan province with the northern hub of Mandalay and from there to the southern hub of Yangon as well as the Kyaukphyu Special Economic Zone (SEZ) where China already has substantial investments. The areas of cooperation are expected to include infrastructure, manufacturing, transport, finance, agriculture, telecommunications, and research and technology among others.

The ethnic armed groups' relationship with the government is primarily constrained by their relationship with the military. Since the NLD-led government has no effective control over the military and the Ministries of Defence, Interior, and Border Affairs, which are also beholden to the military, there is a real sense that the government does not control ground related developments in many areas where there is active fighting. As mentioned earlier, in the two years since the current government has been in power, fighting has actually flared in Kachin and Shan states. And such fighting invariably leads to the displacement of civilian populations in the affected areas leading in turn to a rise in the number of IDPs. U Win Myint, a close confidant of Aung San Suu Kyi who replaced U Htin Kyaw as President in March 2018, is much more politically conscious and active in commenting on national political issues from corruption to the rule of law. He has taken an active interest in the peace process as well and called for patience and magnanimity on the part of all parties.

The hope of the NLD leadership is to be able to persuade the military to change the 2008 Constitution in order to move the peace process forward. While it had attempted other means to make such changes, it now views the peace process as the way to go about doing it. Hence while adhering to its electoral promise to change the Constitution, it now views the ethnic peace process as the means to fulfill that promise. This logic is premised in the belief that the political demands of the ethnic groups and the crafting of a working federal system can only be obtained by changing the Constitution. In this regard, both the government and the ethnic groups appear to be united, albeit the military has thus far not budged from its position that the Constitution is sacrosanct and inviolable. It remains to be seen whether such changes will occur and under what circumstances. 


\section{Conclusion}

The Third Twenty-First Century Panglong Conference that was held in July 2018 saw the accession of two more ethnic armed groups to the NCA of October 2015 that was initiated by the Thein Sein government. The NCA now has ten signatories among the ethnic armed groups and the strengthening of this group has had a deleterious impact on the UNFC that previously represented the nonsignatories collectively. The Northern Alliance continues to remain aloof from the peace process as currently constituted although the UWSA's statement that it would consider signing on to the NCA if it was allowed to exit from it afterwards is a new development. There has been no word on this development since then, and the KIO/KIA, AA, TNLA, and MNDAA from the Alliance continue to be in a state of active fighting with the military. China continues to be the facilitator for meetings between the Northern Alliance on the one hand and the military and the government on the other. While the process is continuing and fluid, many of the ethnic armed groups have expressed their disappointment and frustration at the absence of meaningful political dialogue and change. They have also indicated that they will hold on to their weapons and not abandon their right to secede, which was contained in the original 1947 Panglong Conference proclamation. The latter idea is anathema to the military and it is also trying to push for disarmament, demobilization, and reintegration of the ethnic armies. This is part of a fluid and ongoing process, but it does appear to be stalemated for now with the military being primus inter pares in the negotiation process. Finally, the NLDled government has signaled that it would like to change the 2008 Constitution by persuading the military to further the peace process.

\section{Acknowledgements}

The author would like to thank Tin Maung Maung Than for his comments on an earlier draft of the article.

\section{References}

Chan Thar. 2018. “Two Ethnic Groups Rejoin UNFC.” Myanmar Times, February 27.

Eleven Newmedia. 2018a. "Military Chief Meets Leaders from the Northern Alliance." July 12.

Eleven Newmedia. 2018b. “Tatmadaw and KIO Leaders Meet in China." August 6.

Eleven Newmedia. 2018c. "Ethnic Armed Groups Plan to Hold Ethnic Conference ahead of Fourth Union Peace Conference." July 23.

Ganesan, N. “Changing Dynamics in Myanmar's Ethnic Peace Process and the Growing Role of China." Asian Journal of Peacebuilding 5 (2): 325-339. 
Htet Naing Zaw. 2018. "Senior Chinese Delegation Meets with President, State Counsellor in Naypyitaw." Irrawaddy News, May 9.

Irrawaddy News. 2018. "NCA: The Elephant in the Room at the Peace Conference?" July 21.

Karen News. 2018. "Burma/Myanmar Military Aggression Violates the Nationwide Ceasefire Agreement and Endangers Villagers in Mutraw District, Karen State." March 9.

Lawi Weng. 2018a. "Chinese Whispers in Yangon as Myanmar Weighs Rohingya Deal With UN.” Irrawaddy News, May 31.

Lawi Weng. 2018b. "Peace Process Entirely in Military's Hands, Karen Group Says.” Irrawaddy News, June 6.

Lawi Weng. 2018c. "All Members of Northern Alliance Invited to Attend Panglong Peace Conference." Irrawaddy News, July 4.

Lawi Weng. 2018d. "No Guarantee Not to Secede: Ethnic Armed Group Leaders." Irrawaddy News, September 13.

Lun Min Mang. 2017. "Five More Groups Likely to Sign NCA with Government." Myanmar Times, March 29.

Lun Min Mang. 2018. "New Mon State Party Faces Birthing Pains after Signing Ceasefire Pact." Myanmar Times, March 16.

Maung Htoo. 2018a. "Just Holding Panglong Conference Can’t Solve Root Cause of Political Problem for Country: General Saw Mutu Say Poe." Eleven Newsmedia, July 2.

Maung Htoo. 2018b. "Peace Commission and Northern Alliance Forces Meet." Eleven Newmedia, September 7.

Min Naing Soe. 2018. "Myanmar Can't Tackle Conflicts as long as Essences on Panglong Agreement Can't Be Fulfilled.” Eleven Newsmedia, July 28.

Nan Lwin. 2018a. "Ethnic Political Parties Merge to Seek Stronger Representation in 2020 Election." Irrawaddy News, September 11.

Nan Lwin. 2018b. "Analysis: NLD Cozying Up to Beijing as Ties With West Fray." Irrawaddy News, September 27.

Nan Lwin. 2018c. “Gov’t Signs MoU with Beijing to Build China-Myanmar Economic Corridor." Irrawaddy News, September 13.

Naw Betty Han. 2018a. “Tatmadaw and Govt. Using Peace Process for Centralization: CSOs." Myanmar Times, July 6.

Naw Betty Han. 2018b. "Military, KNU Clashes Erupt in Hpapun." Myanmar Times, August 30.

Nilar. 2018a. "Myanmar, China Ink Strategic Cooperation Framework Agreement." Eleven Newsmedia, April 7.

Nilar. 2018b. "Military, KNU Clashes Erupt in Phapun." Myanmar Times, August 30.

Nyein Nyein. 2018a. "Tatmadaw Clash Again as Fighting Spreads in Phapun District." Irrawaddy News, March 15.

Nyein Nyein. 2018b. "Northern Alliance Seeks Continued Support from China in Peace Process Negotiations.” Irrawaddy News, March 29.

Nyein Nyein. 2018c. "Burma: Military Intransigence Signals Dead End for Peace Process." Irrawaddy News, July 6.

Nyein Nyein. 2018d. "New Mon State Party Leader Frustrated with Process 'Stalemate' But Hopeful." Irrawaddy News, September 11. 
Reuters. 2018. "China Does Not Want UN to Push Myanmar on Accountability." May 9. Ye Mon. 2018. "Controversy, Progress at the Third Panglong Conference." Frontier Myanmar, July 16.

N. Ganesan is a professor of Southeast Asian politics at the Hiroshima Peace Institute in Japan where he has been since 2004. His research interests are in sources of interstate and intrastate tensions in Southeast Asia. Recent major edited works include Conjunctures and Continuities in Southeast Asian Politics (2013) and Bilateral Legacies in East and Southeast Asia (2015). In Myanmar he serves as coordinator and trainer for the civil service (since 2013) and faculty at Yangon and Mandalay Universities (since 2015) with German funding.

Submitted: October 5, 2018; Revised: October 18, 2018; Accepted: October 20, 2018 